\title{
The Role of Social Capital of the Urban Farming Community in the Development of Horticulture in Makassar (Case Study: Women's Group Dewi Sari Lorong Garden, Tamalanrea District)
}

\author{
Nurbaya Busthanul ${ }^{1,}{ }^{*}$, Anwar Sulili ${ }^{1}$, Sitti Bulkis ${ }^{1}$, Tamzil Ibrahim ${ }^{1}$, Yopie Lumoindong ${ }^{1}$, \\ Masyhur Syafiuddin ${ }^{2}$, and Muhammad Arif Naufal ${ }^{1}$ \\ ${ }^{1}$ Department of Agricultural Social Economics, Faculty of Agriculture, Hasanuddin University, \\ Makassar, Indonesia \\ ${ }^{2}$ Department of Soil Science, Faculty of Agriculture, Hasanuddin University, Makassar, Indonesia
}

\begin{abstract}
Social capital is one of the conditions that must be met in the development process. Weak social capital will reduce the spirit of mutual cooperation, exacerbate poverty, increase unemployment and crime and can hinder any efforts to improve social welfare. This research uses a combination method or better known as a mixed method, which is a combination of qualitative research and quantitative research. The results of the study illustrate that in the hallway garden community, the potential for social capital is relatively high as seen through the elements of social capital, trust, institutions and networks. This can be seen in the daily life of the community, such as mutual trust in the harmonious neighbors, kinship, helping nature, mutual help, social solidarity, being cooperative, and all of these appear in the collective behavior of the community in the form of urban farming activities.
\end{abstract}

\section{Introduction}

In the life of modern society as it is today, it is often distinguished between rural and urban communities in the form of "rural community" and "urban community". The characteristics of rural and urban communities can be very different due to several significant differences in their daily way of life and social systems. In urban communities, individuals are usually less dependent on other people, while in villages, residents usually have a close relationship because each other often depends on various things and activities. In cities, the division of labor is clearer and clearer so that the professions have real boundaries and the relationships that exist between the professions are more professional. With the existence of a strict system of division of labor, it is possible to get more jobs in urban communities than rural residents. In a rational and professional mindset in people living in urban areas, there is the possibility of an interaction based on common interests.

*Corresponding author: n.busthanu10963@gmail.com 
The social practice of urban agriculture or what is commonly known as urban farming has now become a practice that is very popular with most urban communities in Indonesia. Urban farming itself has two definitions, namely a narrow understanding and a broad understanding. Urban farming in a narrow sense is gardening activities in the middle of a city or urban suburb. Urban farming in a broad sense is the entire method of food production, starting from cultivation, processing and distribution of foodstuffs in or around cities [1]. Urban Farming in a broad sense can involve farming, aquaculture, agroforestry and horticulture and distributing food within city boundaries [2-5]. So far, the trend of urban farming in various countries is based on the food insecurity experienced by these countries [6,7]. In its continuation, this activity began to transform into a collective action for urban communities in Indonesia.

In the economic development sector, social capital has a very high influence on the development and progress of various economic sectors, one of which is through agriculture $[8,9]$. Social capital is a very important development capital for the life of rural communities [10]. Diniyati in [10] explains that social capital is an important concept and plays a very important role in agricultural development programs [10]. Social capital has a very high influence on the development and progress of various economic sectors [11]. The strength of social relationships is reflected in good behavior, a sense of friendship, mutual sympathy, and fostering close relationships and cooperation among individuals in the family who form a social group in social life [12].

Social capital is an important aspect for developing a more advanced agriculture [13]. Community social capital, such as trust, mutual cooperation, networks and attitudes, play a major role in community behavior and if managed properly, it will be able to empower the community $[14,15]$. Social capital is a shared norm and value generated by trust, where trust is the basis for an attitude of order, honesty, and cooperative behavior that emerges from within a community. The social capital dimension describes everything that makes people ally to achieve common goals on the basis of togetherness [16].

The role of social capital in small-scale agriculture has been widely recognized and the growth effects of social capital can be manifested in networks and trust facilitating access to productive resources and knowledge sharing among farmers [17,18]. Community collective action can be facilitated by social capital and has a strong influence on the process of increasing social welfare $[19,20]$. High social capital will have an impact on high community participation, so that the government will have stronger accountability [21]. A good application of social capital will be able to empower the community and be very influential in the success of sustainable natural resource management [22,23].

Urban farming activities have a special interest to be studied and researched further for the following reasons (1) $50 \%$ of the world's population lives in cities, (2) low-income urban residents spend $40-60 \%$ of their income on food, (3) 250 millions of people who are categorized as vulnerable to hunger are in urban areas, and (4) it is estimated that by 2015 , 26 cities worldwide will have a population of more than 10 million urban residents [24]. Municipal agriculture, if done well and paying attention to environmental aspects, has many advantages. These benefits can be grouped into three, namely: social, economic and environmental benefits. In other words, urban agriculture, if developed in an integrated manner, is an important alternative in realizing sustainable urban development. The existence of urban farming community space in Makassar City is considered to have contributed to the development of green open spaces and city food security, so that more and more community members are interested in carrying out these urban farming activities.

The relationship between the potential for physical development and social capital development, especially in this study, is the development of the garden aisle as a residential space that has a relatively high social capital index and of course contains elements of environmental development itself. This research was conducted to increase the potential of 
the community from the aspect of building a garden hall area based on social capital. So the researcher consciously designed a scientific study entitled: The Role of Community Social Capital 'Urban Farming', in the Development of Horticultural Plants in Lorong Garden, Tamalanrea Village, Tamalanrea District, Makassar City, South Sulawesi. Furthermore, research data processing will be carried out qualitatively-descriptively to provide an overview of how social capital contributes to the development of the garden hall area in Makassar City.

\section{Research methodology}

This study uses a qualitative approach, which is an approach which is also called an investigative approach because researchers usually collect data in a face-to-face manner and integrates with people at the research site. Qualitative research can also be interpreted as research that has the aim of understanding the phenomenon of something that is experienced by the object of research in a holistic manner, and is described in terms of words and language. The purpose of this methodology is not a generalization but an indepth understanding of a problem. Qualitative research serves to provide substantive categories and qualitative research hypotheses [25].

\section{Result and Discussion}

\subsection{Identity of respondents}

The identity of a respondent is very helpful in the research process because can provide information about the condition of the Social Capital of the Urban Farming Community in the Development of Horticultural Plants in Lorong Garden, Tamalanrea Village. The informants in this study were representatives of Dewi Sari's Women Farmers Group in the Village of Tamalanrea as well as administrators of the Women Farmers Group which can be seen in the Table 1.

Table 1. Identity of key and supporting informants

\begin{tabular}{|c|l|c|l|l|}
\hline No. & \multicolumn{1}{|c|}{ Name } & Age & Types of informants & \multicolumn{1}{|c|}{ Position in Society } \\
\hline 1 & Umi & 50 & Key Informants & Counselor \\
\hline 2 & Rusni & 45 & Key Informants & $\begin{array}{l}\text { Head of the Women Farmers } \\
\text { Group, Dewi Sari }\end{array}$ \\
\hline 3 & Nurul Huda & 43 & $\begin{array}{l}\text { Supporting } \\
\text { Informants }\end{array}$ & $\begin{array}{l}\text { Secretary of the Women's Farmer } \\
\text { Group, Dewi Sari }\end{array}$ \\
\hline 4 & Hermawati & 48 & $\begin{array}{l}\text { Supporting } \\
\text { Informants }\end{array}$ & $\begin{array}{l}\text { Treasurer of the Women Farmers } \\
\text { Group, Dewi Sari }\end{array}$ \\
\hline 5 & Sabur & 55 & $\begin{array}{l}\text { Supporting } \\
\text { Informants }\end{array}$ & Public figure \\
\hline
\end{tabular}

The selection of key informants and supporters was taken based on the knowledge they had about the conditions and activities of the women farmer groups. Key informants should be people who are willing to share concepts and knowledge with researchers, and are often used as a place for questions by researchers. Meanwhile, the selection of supporting informants is based on the knowledge of additional information as a complement to the analysis and discussion in the research [26]. Community leaders and members of the Women's Farmers Group, in this case the treasurer and secretary, were selected as supporting informants in the study. 


\subsection{Community knowledge level}

The people of Tamalanrea Village have a community called the female farmer community. This community as a whole consists of women and it is enough to contribute to the development of the garden aisle area because it can transmit urban farming knowledge to the surrounding environment. One of the work units that they (farmer women community) do is the nursery and maintenance of agricultural plants. The community is aware of the existence of urban farming activities from various media sources. This can be understood together because the location of this research is centered in the city of Makassar, which has adequate city facilities, for example the available information network media. When it comes to increasing social capital in society, it is important to have access to information transparency for all levels of society. There are four types of urban farming activities, namely increasing green open space, exploiting empty land, aesthetics of garden aisles, and also improving food security. Public knowledge is considered quite good because considering that this hallway is one of the demonstration centers for garden aisles, especially in the city of Makassar, which can combine elements of environmental wisdom and equal economic benefits of beauty.

\subsection{Elements of community social capital}

\subsubsection{Mutual trust}

In general, from the results of this study, it can be said that the element of trust in the members of Dewi Sari's farmer group in the Tamalanrea Village is high even though there are some people who do not have mutual trust between one another and still have fear of situations that are considered unsafe in Tamalanrea Village. According to him, an individual can also have a social capital that is useful for self-actualization, as well as a garden aisle community that has social trust capital that can be used in optimizing the potentials of their community. This element of belief was grown from the beginning of the formation of the garden hall community. This belief is raised so that each individual has a sense of social responsibility and also fosters high kinship ties between them. This can be seen from the closeness of the members where they can build mutual cooperation more effectively, especially in the sustainability of urban farming activities in Tamalanrea Village. After the growth of trust, cooperation to help each other will be easily built. This is also found in the community in the garden hallway of Tamalanrea Village.

\subsubsection{Network}

In general, from the results of this study it can be said that the network element in the social capital of the members of Dewi Sari's Women Farmers Group in Tamalanrea Village is high because the people in this area still have a sense of close closeness and wide reach to the people around them. both inside and outside the Kelurahan Tamalanrea. Social networks exist thanks to the connectedness between individuals and communities. Linkages exist in various types of social groups at the local level as well as at higher levels. A strong social network among members of the group is absolutely necessary in maintaining the synergy and cohesiveness of the group in carrying out every activity. 


\subsubsection{Social institutions}

In general, from the results of this study, it can be said that the elements of organization owned by the members of the Women Farmers Group in the Village of Tamalanrea are classified as moderate because most of the mothers choose to be self-aware of the applicable rules and try not to violate them. The strengthening of certain social institutions will be able to regulate how communication between groups in the guardian hall society is well developed, does not clash with each other, can work together, understand each other, do not interfere with each other and so on. Social institutions in the community will influence the behavior of its members in each group activity .

\subsection{The role of community social capital}

The role of social capital for the Dewi Sari Woman Farmer Group observed in field research is as follows:

\subsubsection{Sharing of information}

Information Sharing is the continuous flow of communication between partners, both formal and informal, and contributes to better planning and supervision. Dewi Sari's Women Farmer Group has produced a good and successful communication relationship, this can be seen from the information sharing that was carried out where the group uses social media, in this case the Whatsapp Group to continue to build relationships with members. In accordance with Ngangi's theory in [8], sharing information is the key to producing good and successful communication relationships. When someone is committed to sharing information, their internal relationships will be well established. In addition, due to high information sharing from Dewi Sari's Women's Farmer Group, the production of superior horticultural crops (lettuce, spinach and pakcoy) has increased due to the large market demand. The role of farmer respondent sharing in Kelurahan Tamalanrea is measured by the number of sources of information, intensity of information acquisition, information distribution and the level of difficulty of information. For details on this role can be seen in the Table 2.

Table 2. Role of respondent information sharing

\begin{tabular}{|c|l|c|c|}
\hline No. & Interval Score & Number of Respondents (people) & Percentage (\%) \\
\hline 1. & Low (6-10) & 0 & 0 \\
\hline 2. & Medium (11-14) & 12 & 40 \\
\hline 3. & High (15-18) & 18 & 60 \\
\hline Amount & $\mathbf{3 0}$ & $\mathbf{1 0 0}$ \\
\hline
\end{tabular}

\subsubsection{Coordinating activities}

Coordinating activities, where each individual coordinates all activities or work that will be or is being undertaken in order to make it easier to carry out actions and decision making. Wanita Tani Dewi Sari produced a good and successful communication relationship. This can be seen from the information sharing that was carried out where the group also used social media, in this case the Whatsapp Group to continue to establish relationships with members. In accordance with Ngangi's theory in [8], sharing information is the key to producing good and successful communication relationships. When someone is committed 
to sharing information, their internal relationships will be well established. The role of coordinating activities of respondent farmers in Tamalanrea Village is measured by the intensity of farmer cooperation, the number of participants in collaboration, the effect of participating and if not participating. For more details, the role of social capital in coordinating activities can be seen in Table 3 .

Table 3. Role of respondent farmers' coordinating activities

\begin{tabular}{|c|l|c|c|}
\hline No. & Interval Score & Number of Respondents (people) & Percentage (\%) \\
\hline 1. & Low (6-10) & 0 & 0 \\
\hline 2. & Medium (11-14) & 6 & 20 \\
\hline 3. & High (15-18) & 24 & 80 \\
\hline Amount & $\mathbf{3 0}$ & $\mathbf{1 0 0}$ \\
\hline
\end{tabular}

\subsubsection{Making collective decision}

The farmer groups in Tamalanrea Village generally hold regular meetings 3 to 4 times a year. Each meeting discusses different matters such as discussing the planting season simultaneously, coordinating harvest activities, and one meeting also discusses problems experienced during the cultivation process. These further meetings will still be added with incidental meetings if members of the farmer groups feel the need to discuss something that is considered important to be discussed together. Based on the above statement, it can be seen that Dewi Sari's Women's Farmer Group made a decision by conducting deliberation beforehand so that decision making regarding requests was carried out together so as not to burdens each other. The role of farmer respondent collective decision making in Tamalanrea Village is measured through deliberation intensity, number of people deliberating, compliance with deliberation results and deliberation commitment. For more details, the elements of making collective decision can be seen in the following table.

Table 4. The role of making collective decision by respondent farmers

\begin{tabular}{|c|l|c|c|}
\hline No & Interval Score & Number of Respondents (people) & Percentage (\%) \\
\hline 1. & Low (6-10) & 0 & 0 \\
\hline 2. & Medium (11-14) & 0 & 0 \\
\hline 3. & High (15-18) & 30 & 100 \\
\hline Amount & $\mathbf{3 0}$ & $\mathbf{1 0 0}$ \\
\hline
\end{tabular}

\subsection{The role of urban farming}

The existence of agriculture in urban communities can be used as a means to optimize the use of land or house yards and natural resources in the city. In addition, urban residents who are generally busy because of work, urban farming can be a medium to take advantage of their spare time. Optimizing land use and utilizing free time for activities in urban agriculture will bring them closer to access to food and protect the environment by utilizing the house yard.

The benefits felt by each individual have various answers, each individual is given the freedom to choose from one of the benefits they feel. All informants who are involved in urban farming, choose the first order, which is as follows: (1) can create a neat, beautiful, beautiful, and cool alley, which makes this garden aisle still comfortable and conducive to the hallway community, (2) can find out how gardening around the yard of the house with 
narrow and empty land (leftover) by opening educational space through gardening that generates benefits for the surrounding community, (3) can create a clean city by increasing spatial green cities or green residential spaces in the middle of the increasingly urban environment of Makassar. solid, (4) can help the implementation of the $3 \mathrm{R}$ (reuse, reduse, recycle) to maintain waste management by minimizing or reducing bad behavior of the garden aisle community gradually through the provision of a waste bank in every garden aisle in Tamalanrea Village, Makassar City.

\section{Conclusion}

The conclusions that can be given based on the results of this study are the data from qualitative research that examines the elemental variables and the role of social capital in the development of the garden hall area owned by Dewi Sari's female farmer group. Social capital that thrives is represented by the role of social capital in the garden hall community, namely sharing information, making colletive decisions, and coordinating activities. While the element of social capital that exists in the Women Farmers Group Dewi Sari Village Tamalanrea, District Tamalanrea, Makassar is high, which can be seen from the elements of social capital that exists among others, confidence ( trust), social networks ( social networking) and the Social Institution. The role of social capital that exists in the Dewi Sari Women Farmer Group, Tamalanrea Village, Tamalanrea District, Makassar City is also classified as high, which can be seen from the role of social capital that exists, among others, Sharing Information has a relatively high score with a percentage of $60 \%$. Coordinating Activities which have a high score with a percentage of $80 \%$, and the role of Making Collective Decision have a high score with a percentage of $100 \%$.

\section{References}

1. K. Wijaya, A. Y. Permana, S. Hidayat, and H. Wibowo, J. Arsit. ARCADE 4, 16 (2020).

2. V. Süß, Role of Urban Agriculture to Increase Food Security and Economic Resilience of Refugees and Vulnerable Host Communities: The Case of Syrian Refugees in Bourj Hammoud, Lebanon (2018).

3. P. N. Indah, I. T. Amir, and U. Khasan, Agriekonomika 9, 150 (2020).

4. D. W. Olivier and L. Heinecken, Agric. Human Values 34, 743 (2017).

5. I. Z. Bauw, Gerakan Urban Farming: Studi Atas Mobilisasi Sumber Daya Oleh Komunitas Bandung Berkebun (Diss. Universitas Gadjah Mada, Yogyakarta, 2015).

6. D. T. Armanda, J. B. Guinée, and A. Tukker, Glob. Food Sec. 22, 13 (2019).

7. A. R. Fauzi, A. N. Ichniarsyah, and H. Agustin, J. Agroteknologi 10, (2016).

8. J. Rumagit, J. F. J. Timban, and C. R. Ngangi, Agri-Sosioekonomi 15, 453 (2019).

9. P. E. Prasetyo, A. Setyadharma, and N. R. Kistanti, Int. J. Sci. Technol. Res. 9, 6627 (2020).

10. N. Busthanul, M. S. S. Ali, A. Kamaluddin, Heliawaty, and M. T. Saputra, Pengabdi. Kpd. Masy. 789 (2016).

11. P. E. Prasetyo, A. Setyadahrma, and N. R. Kistanti, Int. J. Sci. Technol. Res. 9, 1838 (2020).

12. Kushandajani, Otonomi Desa Berbasis Modal Sosial Dalam Perspektif Socio-Legal (Jurusan Ilmu Pemerintahan Fisip Undip, Semarang, 2008). 
13. M. Harahap and S. Herman, J. Agribus. Sci. 1, 49 (2017).

14. E. Thobias, A. K. Tungka, and J. J. Rogahang, Acta Diurna 1 (2013).

15. E. Juita K. Nababan, R. Qurniati, and A. Kustanti, J. Sylva Lestari 4, 89 (2016).

16. B. Cahyono and A. Adhiatma, Conf. Business, Accounting, Manag. 1, 131 (2012).

17. I. Luginaah, R. B. Kerr, E. Lupafya, and L. Dakishoni, Int. J. Sustain. Dev. World Ecol. 7, 1 (2020).

18. O. Kolade, O. Mafimisebi, and O. Aluko, Int. J. Palgrave Handb. Agric. Rural Dev. Africa 109 (2020).

19. N. T. Puspita, R. Qurniati, and I. G. Febryano, J. Sylva Lestari 20, 54 (2020).

20. R. Qurniati, I. G. Febryano, and D. Zulfiani, Biodiversitas 18, 1201 (2017).

21. S. Ekawati and D. Ridho Nurrochmat, J. Anal. Kebijak. Kehutan. 11, 40 (2014).

22. Nurrochmat, D. Ridho, D. Darusman, and M. Ekayani., Kebijakan Pembangunan Kehutanan Dan Lingkungan Teori Dan Implementasi (PT Penerbit IPB Press, Bogor, 2016).

23. T. Pranadji, J. Agro Ekon. Indones. Agency Agric. Res. Dev. 24, 178 (2016).

24. A. N. Jamaludin, Sosiologi Pembangunan (CV Pustaka Setia, Bandung, 2016).

25. M. P. Sumiyati, Al-Astar 5, 56 (2017).

26. E. Martha and S. Kresno, Metodologi Penelitian Kualitatif (Rajawali Press, Jakarta, 2016). 